\title{
Pengembangan Media Interaktif Berbasis Game Edukasi dalam Meningkatkan Kreativitas Guru Sekolah Dasar di Masa Pandemi Covid-19
}

\author{
Fattachul Huda Aminuddin, Teuku Djauhari, Merti Megawaty \\ Universitas Nurdin Hamzah, Jl.Kolonel Abunjani, RT.25 Selamat Danau Teluk, Selamat, Kec. Telanaipura, Kota Jambi, Jambi 36124
}

\section{ARTICLE INFORMATION}

Received: July 08, 2021

Revised: September $10^{\text {th }}, 2021$

Available online: September $30^{\text {th }}, 2021$

\section{KEYWORDS}

Covid-19, Quizizz, Interactive Media, Training, Creativity.

\section{CORRESPONDENCE}

Phone: 085367875828

E-mail: fattachulhuda@unh.ac.id

\section{A $\quad$ B $\quad \boldsymbol{S}$ T $\mathbf{T}$ R A $\mathbf{A}$ C $\mathbf{T}$}

The presence of the Covid-19 Virus in the world has not only changed the learning culture, but has become a new challenge in developing teacher creativity in the teaching and learning process. This conventional learning pattern that has evolved into technology-based distance learning requires teachers to be able to adapt and adapt to the limited learning needs of students during the pandemic. Digital technology tools are currently very developed, but they are enough to help educators to adapt to the diverse learning needs of today's students. So it is necessary to use the right learning media in carrying out learning during the pandemic. This training aims to train abilities and skills in increasing the creativity of teachers in using interactive learning media during the pandemic using the Quizizz platform. Quizizz is an interactive game-based online platform that can be used in a fun teaching and learning process during the Covid-19 pandemic by utilizing an Android smartphone. The method used is the lecture method and interactive training by involving the teacher as a simulation model.

\section{PENDAHULUAN}

Berdasarkan Surat Edaran Mendikbud Nomor 4 Tahun 2020, bahwasanya kebijakan pendidikan dalam masa darurat pandemi covid-19 salah satunya adalah siswa belajar dari rumah. Tercatat sebanyak 68,8 juta siswa belajar dari rumah, sedangkan untuk guru dan dosen sebanyak 4,2 juta yang belajar dari rumah atau work from home [3]. Tentunya hal ini menjadi budaya dan tantangan baru bagi tenaga pendidik dengan tetap melaksanakan kegiatan belajar mengajar (KBM) secara virtual dengan memanfaatkan teknologi internet atau dikenal dengan istilah pembelajaran sistem daring.

Hadirnya platform online yang digunakan dalam pembelajaran tatap muka secara virtual selama pandemi tentunya diharapkan dapat membantu para guru dalam proses belajar mengajar diantaranya yang sering digunakan seperti Zoom Meeting, Google Meet, Webex. Beberapa sekolah juga banyak telah menerapkan pembelajaran menggunakan menggunakan $1 \mathrm{~ms}$ (learning management system) seperti, google classroom, Zenius, Edmodo, Ruang Guru, dan rumahbelajar. Namun dalam pelaksanaanya tentunya hal ini menimbulkan berbagai macam problematika yang dirasakan siswa dan guru dalam menerapkan pola pembelajaran daring seperti, keterbatasan penguasaan teknologi oleh guru dan siswa, sarana dan prasarana yang kurang memadai, akses internet yang terbatas, serta kurang siapnya penyediaan anggaran [1].
Salah satu pendidikan yang menerapkan pembelajaran jarak jauh (PJJ) adalah SDN 074/IX Desa Suka Makmur Kecamatan Sungai Bahar 01, Kabupaten Muaro Jambi. Berdasarkan hasil wawancara beberapa guru dari total 14 jumlah guru yang mengajar, beberapa guru sudah menerapkan pola pembelajaran daring dengan memanfaatkan platform rumahbelajar, dan google meet, namun masih belum optimal karena dianggap cukup sulit dalam penggunaannya. Mayoritas guru dalam melaksakan pembelajaran daring cenderung memanfaatkan media komunikasi seperti whatsapp karena dianggap lebih mudah dan familiar. Metode yang diterapkan adalah dengan menerapkan pola pembelajaran group discussion terhadap peserta didik, dan didampingi oleh orang tua. Guru memberikan materi, latihan, dan tugas mandiri melalui grup diskusi siswa baik berupa teks, gambar, audio dan video sesuai dengan tema pembelajaran.

Faktanya pola pembelajaran seperti ini kurang efektif jika diterapkan pada siswa-siswi sekolah dasar, dimana guru tidak langsung berdampingan dengan siswa dalam mengukur pemahaman dan pencapaian belajar siswa terhadap materi yang disampaikan. Hal ini berkaitan dengan tahap perkembangan intelektual siswa sekolah dasar yang masih berada dalam tahap operasional konkret dimana siswa belum mampu mengkonstruk pengetahuan yang sifatnya abstrak sehingga harus ditunjang dengan penggunaan media pembelajaran atau alat peraga [2].

Agar tetap tercapai pembelajaran yang lebih kondusif dan tetap menyenangkan di masa pandemi, tentunya guru harus 
memiliki kreativitas dalam mengajar termasuk dalam menggunakan media pembelajaran interaktif. Proses pembelajaran online di masa pandemi sangatlah memiliki keterbatasan, baik dari komunikasi, pengawasan, waktu, tempat, dan interaksi. Tentunya dalam hal ini guru harus dapat berinovasi dan memahami karakteristik media pembelajaran yang menarik, memiliki sifat interaktif yang mengutamakan kerjasama, komunikasi, dan bisa menimbulkan interaksi antar siswa adalah sebuah permainan, permainan, yang mempunyai karakteristik untuk menciptakan motivasi dalam belajar, yaitu khayalan (fantasy), tantangan (challenges) dan keingintahuan (curiosity) [4].

Salah satu media pembelajaran interaktif yang dapat dimanfaatkan dan dikembangkan di masa pandemi adalah Quizizz. Media Quizizz merupakan aplikasi permainan yang sifatnya naratif dan fleksibel, selain dapat dimanfaatkan sebagai sarana penyampaian materi, Quizizz juga bisa digunakan sebagai media evaluasi pembelajaran yang menarik dan menyenangkan [5]. Faktanya pembelajaran online di lapangan masih sering terjadi kendala seperi kurangnya kemampuan guru dalam mengoperasikan platform belajar online seperti zoom meeting, google classroom, quizziz, atau moodle yang khusus dibuat oleh sebuah institusi Pendidikan [6]. Tujuan pelatihan pengembangan ini adalah memberikan pengalaman, dan meningkatkan kreativitas belajar para guru di masa pandemi covid-19 dengan platform Quizizz. Selain itu penelitian ini juga mengajak para guru untuk mengemas media pembelajaran dalam bentuk quis interaktif.

\section{Proses pembelajaran menggunakan}

WA dan dibagikan ke siswa

melalui teks, audio, dan video

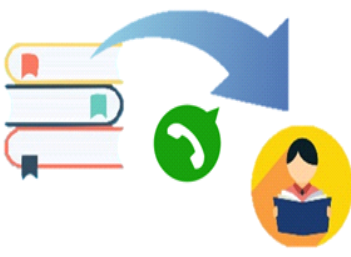

Pola Pembelajaran yang sedang berjalan

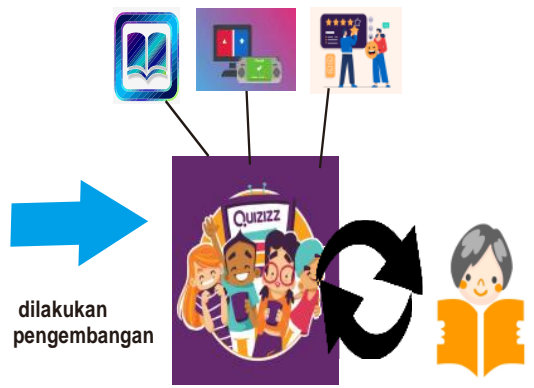

Gambar 1. Konsep Pengembangan

\section{METODE}

Pelaksanaan kegiatan penelitian ini dilaksanakan selama 2 hari yakni ada tanggal 3 - 4 Maret 2021 bersama Guru SDN 074/IX di Desa Suka Makmur, Kecamatan Sungai Bahar, Kabupaten Muaro Jambi, Provinsi Jambi yang berjumlah 14 Guru. Kegiatan penelitian ini melatih guru secara langsung secara langsung di kelas dengan menerapkan protokol kesehatan. Metode yang digunakan dalam penelitian ini adalah penelitian pengembangan (research and development), yaitu konsep dasar penelitian dan pengembangan, konsep ini sangat tepat untuk penelitian efektifitas media pembelajaran, tujuan dari konsep ini yakni peneliti dapat mengembangkan media pembelajaran yang dibuat dalam penelitiannya, pengembangan ini dilakukan dengan tujuan agar media pembelajaran yang di gunakan dapat di kembangkan dan mengalami peningkatan, untuk kepantingan mempermudah kegiatan belajar mengajar dan membuat kegiatan belajar mengajar menjadi lebih bermakna dan tentunya juga efisien [7]. Model penelitian ini menggunakan model desain pembelajaran ADDIE (Analysis, Desain, Development, Implement, Evaluate) dengan dasar pembelajaran bahwa model tersebut cocok untuk mengembangkan media belajar yang tepat sasaran, efektif dan sangat membantu guru dalam proses pembelajaran di masa pandemic Covid-19.

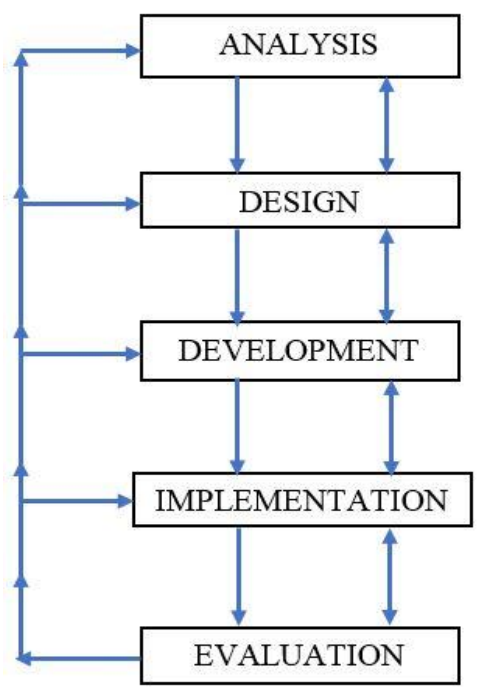

Gambar 2. Model Penelitian Pengembangan ADDIE [8]

a. Tahap Analisis (Analysis)

Pada tahap analisis, peneliti menentukan karakter atau kelompok pengguna dan kemampuan dalam pengoperasian, dan pengoptimalan media Quizizz yaitu para Guru Sekolah Dasar SDN 074/IX Desa Suka Makmur Kec. Sungai Bahar. Pemilihan media interaktif Quizizz yang akan digunakan adalah berasal dari observasi awal dan pertimbangan hasil wawancara oleh guru terhadap kondisi yang dialami serta beberapa survey penelitian yang dari analisis kebutuhan berdasarkan kemudahan dalam penggunaan, interaktifitas media, serta fitur-fitur yang ada untuk mendukung proses belajar mengajar di masa pandemi covid-19.

Tabel 1. Hasil Observasi Awal Responden Wawancara terhadap Guru

\begin{tabular}{cllr}
\hline $\begin{array}{c}\text { Guru yang } \\
\text { diwawancara }\end{array}$ & \multicolumn{2}{c}{ Temuan } & \multicolumn{2}{c}{ Tindak lanjut } \\
\hline Sulomo, S.Pd & $\begin{array}{l}\text { Hadirnya aplikasi } \\
\text { seperti zoom, google } \\
\text { classroom, dan media }\end{array}$ & pembelajaran ong praktis, mudah, \\
& video conference & dan tentunya menarik \\
& lainnya masih belum & bagi anak-anak \\
& sepenuhnya digunakan. & \\
& Media ini masih & \\
& tergolong cukup sulit & \\
& bagi anak-anak, perlu & \\
& media yang tepat & \\
\hline
\end{tabular}




\begin{tabular}{|c|c|c|}
\hline $\begin{array}{l}\text { Sunarmi, } \\
\text { S.Pd }\end{array}$ & $\begin{array}{l}\text { Guru masih belum } \\
\text { familiar terhadap } \\
\text { media yang sudah } \\
\text { digunakan, seperti } \\
\text { video conference. } \\
\text { Karena cukup sulit } \\
\text { mengontrol belajar } \\
\text { anak-anak jika hanya } \\
\text { menggunakan kamera } \\
\text { webcam. Dan yang } \\
\text { paling sulit adalah } \\
\text { kendala jaringan yang } \\
\text { kurang stabil. }\end{array}$ & $\begin{array}{l}\text { Perlu nya media } \\
\text { pembelajaran yang } \\
\text { mudah bagi guru, serta } \\
\text { pengadaan pelatihan } \\
\text { agar guru dapat } \\
\text { memaksimalkan media } \\
\text { tersebut }\end{array}$ \\
\hline $\begin{array}{l}\text { Ika } \\
\text { Widianingsih, } \\
\text { S.Pd }\end{array}$ & $\begin{array}{lr}\text { Guru } & \text { terbiasa } \\
\text { menggunakan WA, } \\
\text { karena lebih praktis } \\
\text { dan mudah. Guru, } \\
\text { siswa dan Wali murid } \\
\text { tergabung menjadi } 1 \\
\text { grup sehingga lebih } \\
\text { mudah terkontrol }\end{array}$ & $\begin{array}{l}\text { Perlunta inovasi dan } \\
\text { ide kreatifitas guru } \\
\text { dalam } \\
\text { mengembangkan } \\
\text { media pembelajaran }\end{array}$ \\
\hline $\begin{array}{l}\text { Uswatun } \\
\text { Khasanah, } \\
\text { S.Pd }\end{array}$ & $\begin{array}{l}\text { Menggunakan video } \\
\text { conference cukup sulit } \\
\text { mengontrol anak-anak } \\
\text { belajar, karena sibuk } \\
\text { bermain sendiri dan } \\
\text { tidak fokus terhadap } \\
\text { materi }\end{array}$ & $\begin{array}{lr}\text { Perlunya pengelolaan } \\
\text { dan } & \text { manajemen } \\
\text { pembelajaran } & \text { yang } \\
\text { tepat } & \text { terhadap } \\
\text { kebutuhan } & \text { belajar } \\
\text { siswa } & \end{array}$ \\
\hline $\begin{array}{l}\text { Siti Fatimah, } \\
\text { S.Pd.i }\end{array}$ & \begin{tabular}{l}
\multicolumn{2}{l}{ Siswa menerima tugas, } \\
Latihan, materi, \\
,melalui WA. Dan \\
menerapkan grup \\
diskusi
\end{tabular} & $\begin{array}{l}\text { Perlunya pembelajaran } \\
\text { berbasis game, agar } \\
\text { siswa tidak cepat } \\
\text { bosan, dan tentunya } \\
\text { perlu media } \\
\text { pembelajaran yang } \\
\text { dapat merangsang } \\
\text { siswa belajar }\end{array}$ \\
\hline
\end{tabular}

b. Tahap Perancangan (Design)

Pada tahap perancangan, peneliti memanfaatkan platform yang sudah disediakan yaitu media Quizizz yang akan digunakan guru dan siswa sebagai media interaktif dalam proses belajar mengajar di masa pandemi covid-19. Tahap ini peneliti memberikan gambaran terhadap pengenalan media Quizizz, penggunaan media, fitur, dan tahapan proses yang akan dirancang dalam membuat media interaktif menggunakan Quizizz.
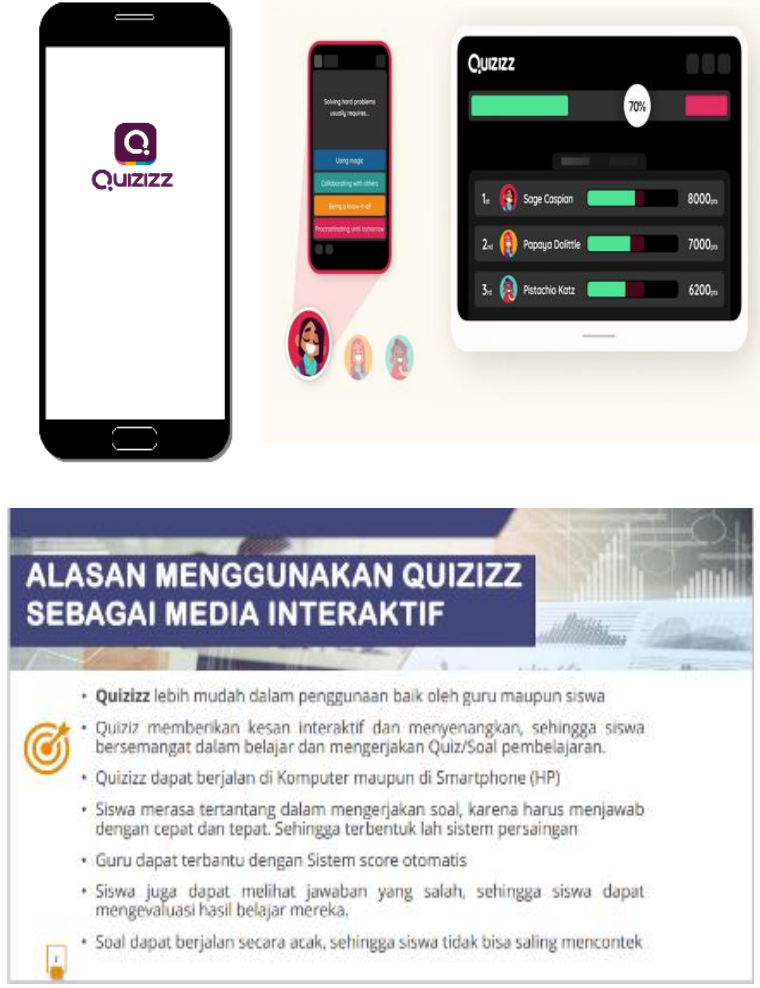

Gambar 3. Konsep Dasar Pengenalan Media Quizizz

Pada tahap penelitian ini, peneliti melibatkan para peserta guru untuk pembuatan akun email aktif yang akan digunakan pada media Quizizz. Tahap awal masing-masing guru mengunduh aplikasi yang tersedia pada playstore pada smartphone, namun jika menggunakan komputer/labtop guru dapat mengakses situs resmi www.quizizz.com. Tahap selanjutnya guru membuat email aktif menggunakan gmail, lalu mendaftarkan email yang sudah aktif untuk digunakan pada media Quizizz. Peserta guru merancang komponen pembelajaran instrumen soal dan materi yang akan digunakan sesuai dengan mata pelajaran yang diampu. Materi dirancang berdasarkan kurikulum, RPP dan silabus guru masing-masing bidang yang akan diajarkan kepada siswa.

Sumber materi disesuaikan dengan sumber yang digunakan guru dalam mengajar seperti buku paket, e-book, video pembelajaran, artikel, hand-book atau sumber lainnya. Peneliti juga menjelaskan berbagai fitur jenis soal yang bisa digunakan, sehingga masing-masing guru dapat membuat kreativitas sendiri dalam mengembangkan bentuk soal yang akan digunakan dalam pembuatan quis game interaktif. Media Quizizz yang akan digunakan dapat berjalan melalui PC/Labtop maupun smartphone sehingga penggunaan lebih praktis. Alur proses pada penelitian pengembangan ini dijelaskan seperti gambar di bawah : 


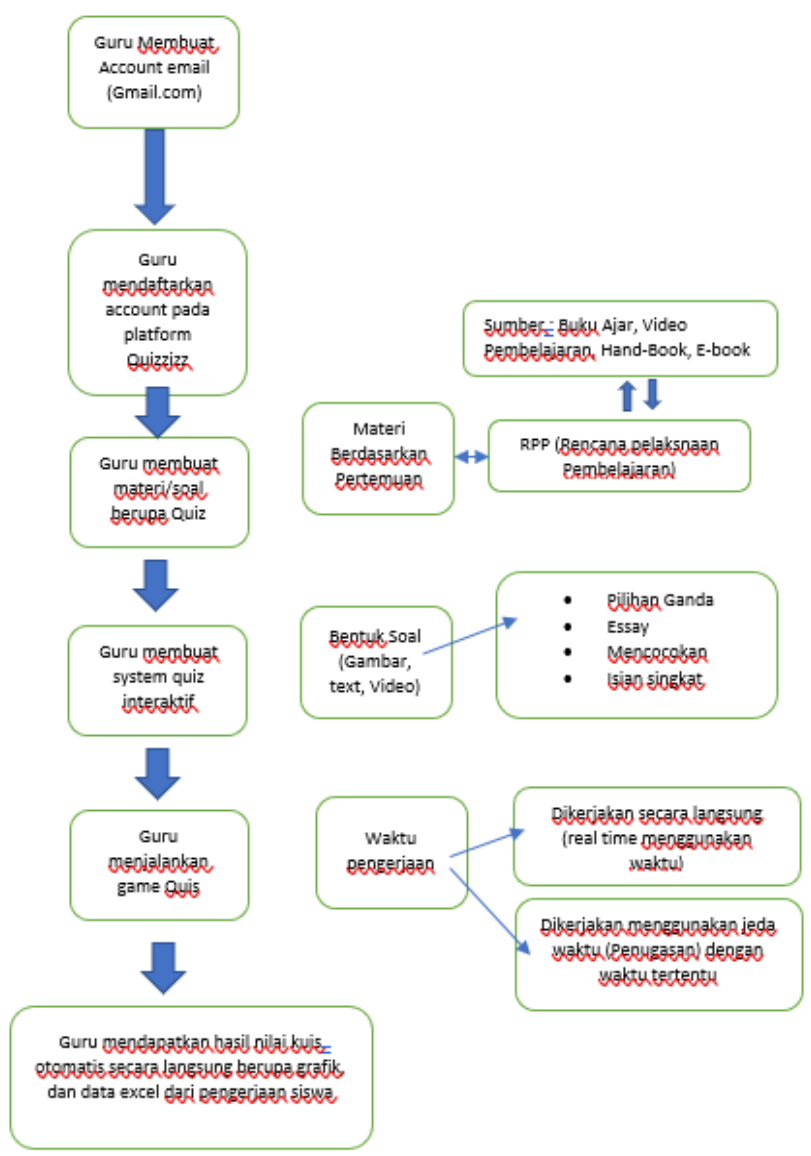

d. Tahap Implementasi (Implementation)

Pada tahap ini, guru menjalankan game interaktif yang sudah dirancang berdasarkan materi dan soal masingmasing. Peneliti menggunakan guru sebagai sampel dalam proses game interaktif.

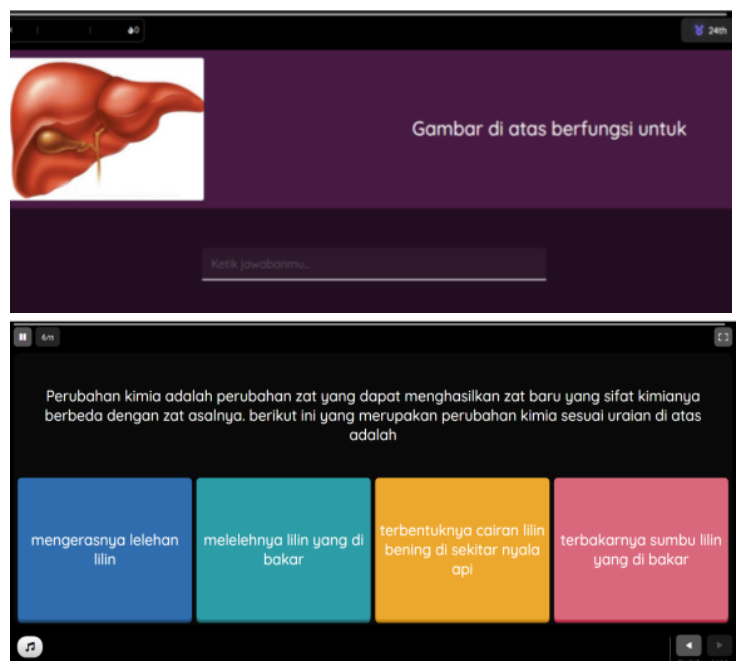

Gambar 6. Implementasi Soal Quis

Pada tahap ini, hasil nilai jawaban quis akan langsung muncul di akhir sesi quis. Setiap sesi pertanyaan akan memunculkan jawaban yang benar dan salah, sehingga dapat di evaluasi. Hasil pengerjaan juga dapat dicetak dan diberikan siswa

c. Tahap Pengembangan (Development)

Pada tahap pengembangan, peneliti melibatkan guru dalam proses membuat soal interaktif menggunakan Quizizz. Guru mendesain dan menginputkan materi soal dalam bentuk quis interaktif berdasarkan materi yang sudah didesain untuk pembelajaran siswa, baik dalam bentuk teks, gambar, audio dan video. Pada tahap ini guru dapat mengatur sistem pengerjaan quis, seperti pengacakan soal, pengaturan nilai, waktu pengerjaan, animasi gambar, pengaturan kunci jawaban, dan beberapa fitur yang bisa dimanfaatkan lainnya. Guru juga dapat mengatur jenis soal yang akan dibuat seperti pilihan ganda, essai, isian singkat, menjodohkan dan survei.
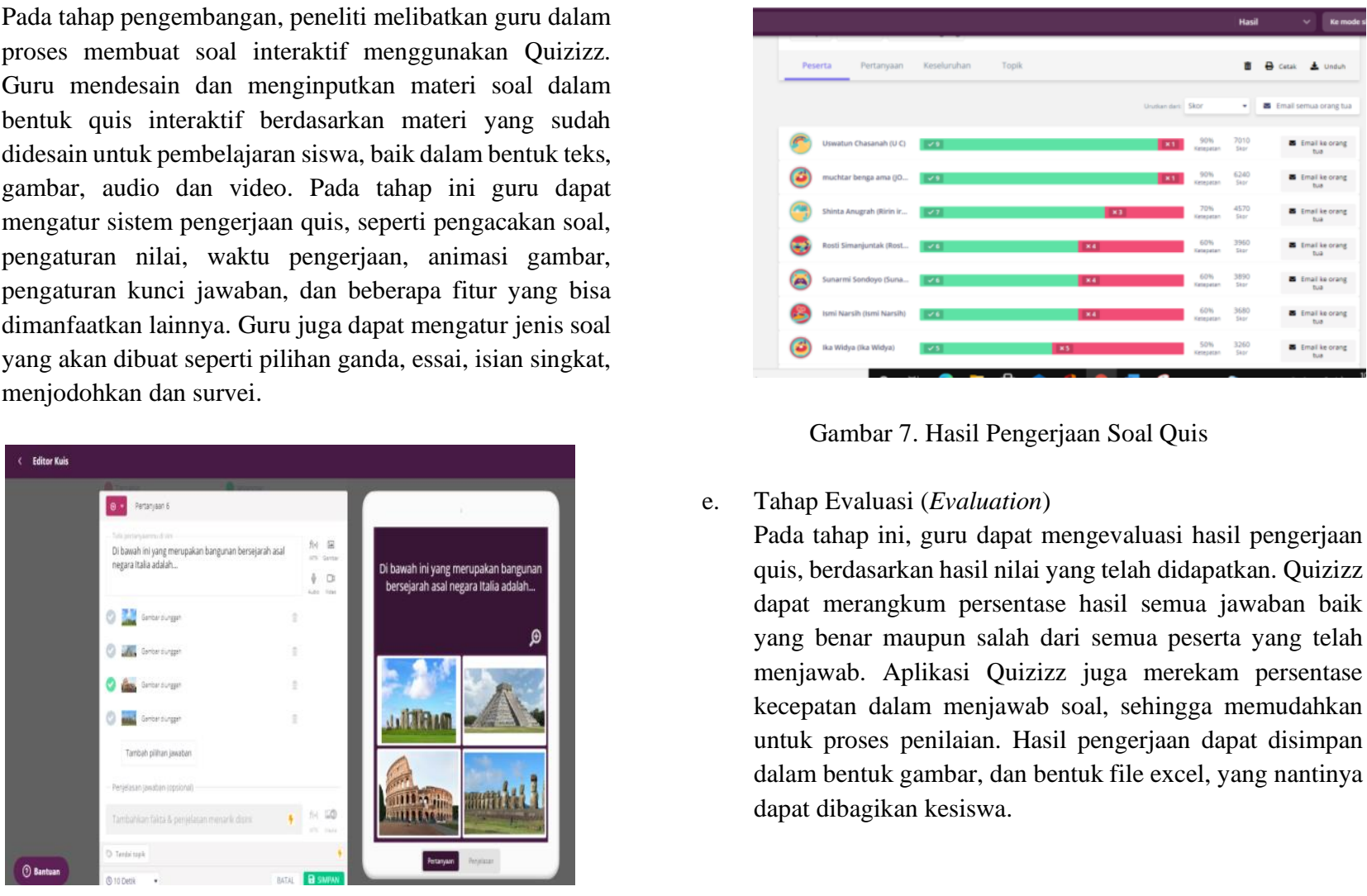

Gambar 7. Hasil Pengerjaan Soal Quis

e. Tahap Evaluasi (Evaluation)

Pada tahap ini, guru dapat mengevaluasi hasil pengerjaan quis, berdasarkan hasil nilai yang telah didapatkan. Quizizz dapat merangkum persentase hasil semua jawaban baik yang benar maupun salah dari semua peserta yang telah menjawab. Aplikasi Quizizz juga merekam persentase kecepatan dalam menjawab soal, sehingga memudahkan untuk proses penilaian. Hasil pengerjaan dapat disimpan dalam bentuk gambar, dan bentuk file excel, yang nantinya dapat dibagikan kesiswa.

Gambar 5. Rancangan Soal Kuis Interaktif 

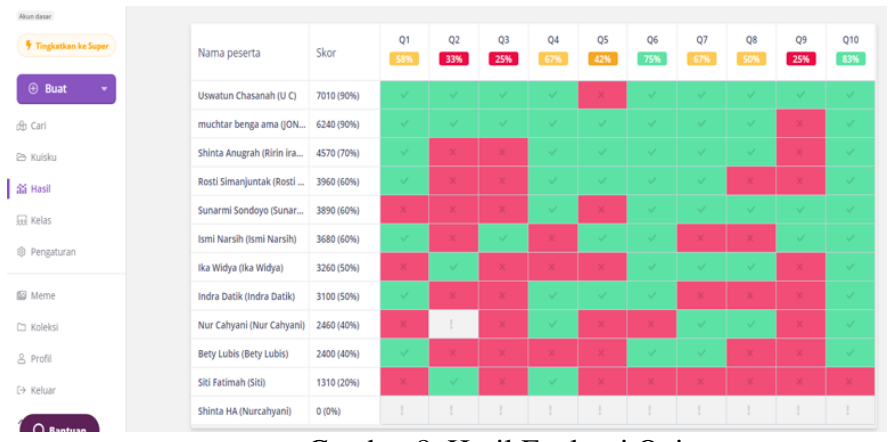

Gambar 8. Hasil Evaluasi Quis

\section{HASIL DAN PEMBAHASAN}

\section{Perencanaan}

Kegiatan-kegiatan yang dilakukan pada tahap perencanaan adalah melakukan perijinan pada sekolah mitra yang akan dijadikan lokasi pelatihan dan pelaksanaan tahap ini didahului dengan mengirim surat pemberitahuan kepada pihak sekolah. Tim melakukan survey sekolah dasar SDN 074/IX Desa Suka Makmur Kecamatan Sungai Bahar, Kabupaten Muaro Jambi dan menemui kepala sekolah untuk koordinasi dalam membahas teknis pelaksanaan kegiatan pelatihan. Kegiatan pelatihan dilaksanakan pada tanggal 03-04 April 2021.

Setelah melakukan survey, tim melakukan wawancara terhadap beberapa untuk memetakan aplikasi apa saja yang digunakan selama pembelajaran daring di masa pandemic Covid19. Dari hasil wawancara, diperoleh hasil sebanyak $78 \%$ guru menggunakan WA grup sebagai sarana pembelajaran daring, sisanya menggunakan aplikasi rumahbelajar dan google classroom. Penyusunan program materi pelatihan yan dirancang selama 12 Jam dalam waktu 2 hari. Berikut adalah materi pelaksanaan kegiatan pelatihan pengembangan

Tabel 2. Jadwal Kegiatan Pelatihan Pengembangan Media Quizizz

\begin{tabular}{clcc}
\hline No & Materi Kegiatan & Waktu & Jam \\
\hline 1. & Konsep Belajar dan & $08.00-$ & 1 Jam \\
& Media Pembelajaran & 09.00 & \\
& Interakfif & & \\
\hline 2 & Konsep Quizizz dan & $09.00-$ & 1 Jam \\
& Media Pembelajaran & 10.00 & \\
& Interaktif & & \\
\hline 3 & Pembuatan Account & $10.00-$ & 2 Jam \\
& E-mail dan Aktivasi & 12.00 & \\
\hline 4 & Instalasi Aplikasi \& & $13.00-$ & 1 Jam \\
& Pembuatan Account & 14.00 & \\
& pada Media Quizizz & & 1 Jam \\
\hline 5 & Fitur dan Kegunaan & 14.00 & 6 Jam \\
\hline
\end{tabular}

Tabel 3. Tanggal Pelaksanaan : Minggu, 04 April 2021

\begin{tabular}{cccc}
\hline No & Materi Kegiatan & Waktu & Jam \\
\hline 1. & $\begin{array}{c}\text { Teknis Pembuatan } \\
\text { Kuis }\end{array}$ & $08.00-09.00$ & 1 Jam \\
\hline 2 & $\begin{array}{c}\text { Manajemen dan } \\
\text { Pengaturan Kuis }\end{array}$ & $09.00-10.00$ & 1 Jam \\
\hline 3 & Kuis Game Interaktif & $10.00-12.00$ & 2 Jam \\
\hline 4 & Share Quiz & $13.00-14.00$ & 1 Jam \\
\hline 5 & Rekapitulasi Nilai & $14.00-15.00$ & 1 Jam \\
Quis & 6 Jam
\end{tabular}

\section{Evaluasi}

Pada tahap ini masing-masing guru berpartisipasi dalam mengisi kusioner tehadap pelaksanaan pelatihan selama 2 hari, yaitu pada tanggal 03-04 April 2021. Kusioner dilakukan bertujuan untuk memberikan evaluasi terkait pelaksanaan pelatihan, agar kegiatan pelatihan selanjutnya dapat terlaksana lebih baik lagi. Terdapat beberapa aspek respon yang di isi oleh guru, yaitu aspek isi materi yang disampaikan oleh peneliti, aspek media, dan pelaksanaan kegiatan. Hasil respon diberikan masing-masing guru secara objektif. Berikut adalah tabel hasil rekapitulasi hasil evaluasi penelitian berdasarkan aspek isi materi pada pelatihan pengembangan media di SDN 074/IX Desa Suka Makmur, Kecamatan Sungai Bahar Kabupaten Muaro Jambi.

Tabel 4. Rekapitulasi Hasil Respon Guru Terhadap Aspek Isi Materi

\begin{tabular}{|c|c|c|c|}
\hline $\mathrm{NO}$ & Aspek Penilaian & $\begin{array}{l}\text { Presentasi } \\
\text { Respon } \\
\text { guru } \\
\end{array}$ & Kategori \\
\hline 1 & $\begin{array}{l}\text { Penyampaian materi tersampaikan } \\
\text { dengan baik, terkonsep, dan mudah } \\
\text { di mengerti }\end{array}$ & 80,72 & $\begin{array}{l}\text { Sangat } \\
\text { Setuju }\end{array}$ \\
\hline 2 & $\begin{array}{l}\text { Isi materi jelas, rinci dan terstruktur } \\
\text { dengan baik }\end{array}$ & 85,30 & $\begin{array}{l}\text { Sangat } \\
\text { Setuju }\end{array}$ \\
\hline 3 & $\begin{array}{l}\text { Materi dan penjelasan dapat } \\
\text { dipahami dengan baik }\end{array}$ & 82,20 & $\begin{array}{l}\text { Sangat } \\
\text { Setuju }\end{array}$ \\
\hline 4 & $\begin{array}{l}\text { Materi dapat diterapkan dan } \\
\text { diujicoba dengan baik dalam } \\
\text { pelaksanaan pelatihan maupun } \\
\text { kepada siswa }\end{array}$ & 79,20 & Setuju \\
\hline 5 & $\begin{array}{l}\text { Dengan materi ini, memberikan } \\
\text { pengetahuan dan ilmu baru tentang } \\
\text { pemanfaatan media interaktif } \\
\text { quizizz di masa pandemi covid-19 }\end{array}$ & 93,67 & $\begin{array}{l}\text { Sangat } \\
\text { Setuju }\end{array}$ \\
\hline 6 & $\begin{array}{l}\text { Materi ini sesuai dengan apa yang } \\
\text { diharapkan }\end{array}$ & 90.27 & $\begin{array}{l}\text { Sangat } \\
\text { Setuju }\end{array}$ \\
\hline 7 & $\begin{array}{l}\text { Materi ini sangat mudah dipelajari } \\
\text { dan dikembangkan }\end{array}$ & 78.03 & Setuju \\
\hline
\end{tabular}

Selanjutnya guru mengisi kusioner terhadap aspek media Quizizz. Aspek ini mengevaluasi terkait segi kemudahan, penggunaan dan manfaat media Quizizz dalam proses pembelajaran di masa pandemi Covid-19. Berikut adalah tabel hasil rekapitulasi hasil evaluasi penelitian berdasarkan aspek media Quizizz. 
Tabel 5. Rekapitulasi Hasil Respon Guru Terhadap Aspek Media

\begin{tabular}{|c|c|c|c|}
\hline NO & Aspek Penilaian & $\begin{array}{l}\text { Presentasi } \\
\text { Respon } \\
\text { guru }\end{array}$ & Kategori \\
\hline 1 & $\begin{array}{l}\text { Media Quizzizz sangat menarik } \\
\text { jika diterapkan kepada siswa di } \\
\text { masa pandemi }\end{array}$ & 87,32 & $\begin{array}{l}\text { Sangat } \\
\text { Setuju }\end{array}$ \\
\hline 2 & $\begin{array}{l}\text { Media Quizzizz sangat mudah dan } \\
\text { praktis digunakan dalam proses } \\
\text { belajar mengajar }\end{array}$ & 79,34 & Setuju \\
\hline 3 & $\begin{array}{l}\text { Media Quizizz dapat dijadikan } \\
\text { sebagai media alternatif dalam } \\
\text { proses belajar mengajar di masa } \\
\text { pandemi }\end{array}$ & 92,20 & $\begin{array}{l}\text { Sangat } \\
\text { Setuju }\end{array}$ \\
\hline 4 & $\begin{array}{l}\text { Media Quizizz dapat membantu } \\
\text { siswa dalam memahami materi } \\
\text { pelajaran, karena menerapkan } \\
\text { konsep game kuis, sehingga materi } \\
\text { menjadi menarik dan tidak } \\
\text { monoton }\end{array}$ & 85,20 & $\begin{array}{l}\text { Sangat } \\
\text { Setuju }\end{array}$ \\
\hline 5 & $\begin{array}{l}\text { Dengan materi ini, memberikan } \\
\text { pengetahuan dan ilmu baru tentang } \\
\text { pemanfaatan media interaktif } \\
\text { quizizz di masa pandemi covid-19 }\end{array}$ & 93,67 & $\begin{array}{l}\text { Sangat } \\
\text { Setuju }\end{array}$ \\
\hline 6 & $\begin{array}{l}\text { Quizizz tidak hanya bisa } \\
\text { diterapkan kepada siswa saja, } \\
\text { namun dapat diterapkan sesama } \\
\text { para guru }\end{array}$ & 82,79 & $\begin{array}{l}\text { Sangat } \\
\text { Setuju }\end{array}$ \\
\hline
\end{tabular}

Tahap terakhir guru, mengisi kusioner penelitian terhadap pelaksanaan pelatihan. Berikut adalah tabel hasil rekapitulasi hasil evaluasi penelitian berdasarkan aspek pelaksanaan kegiatan

Tabel 6. Rekapitulasi Hasil Respon Guru Terhadap Pelaksanaan Kegiatan

\begin{tabular}{|c|c|c|c|}
\hline $\mathrm{NO}$ & Aspek Penilaian & $\begin{array}{l}\text { Presentasi } \\
\text { Respon } \\
\text { guru }\end{array}$ & Kategori \\
\hline 1 & $\begin{array}{l}\text { Selama pelaksanaan kegiatan } \\
\text { berlangsung, penyampaian baik } \\
\text { dari segi materi, penyampaian } \\
\text { instruktur maupun penugasan } \\
\text { sesuai dan tidak terburu-buru }\end{array}$ & 78.56 & Setuju \\
\hline 2 & $\begin{array}{l}\text { Selama pelaksanaan kegiatan } \\
\text { berlangsung, keseluruhan materi } \\
\text { dapat dipahami baik dari konsep } \\
\text { dan teknis }\end{array}$ & 76,32 & Setuju \\
\hline 3 & $\begin{array}{l}\text { Selama pelaksanaan kegiatan } \\
\text { berlangsung, saya tetap fokus dan } \\
\text { dapat mengikuti materi hingga } \\
\text { akhir }\end{array}$ & 80.20 & $\begin{array}{l}\text { Sangat } \\
\text { Setuju }\end{array}$ \\
\hline 4 & $\begin{array}{l}\text { Dalam pelaksanaan kegiatan, baik } \\
\text { dari segi materi, penyampaian, dan } \\
\text { penugasan, memberikan saya } \\
\text { motivasi untuk terus belajar }\end{array}$ & 84,20 & $\begin{array}{l}\text { Sangat } \\
\text { Setuju }\end{array}$ \\
\hline 5 & $\begin{array}{l}\text { Selama kegiatan berlangsung, saya } \\
\text { dapat mengikuti instruksi tanpa } \\
\text { mengalami kendala teknis }\end{array}$ & 72.43 & Setuju \\
\hline
\end{tabular}

Berdasarkan hasil tabel rekapitulasi di atas, peneliti dapat berdasarkan tingkat capaian pelaksanaan pelatihan yaitu sebagai berikut.

Tabel 7 Tingkat Capaian Pelaksanaan Pelatihan.

\begin{tabular}{|c|c|c|}
\hline $\mathrm{NO}$ & $\begin{array}{c}\text { Indikator } \\
\text { Ketercapaian }\end{array}$ & Tingkat Capaian \\
\hline 1 & \begin{tabular}{lr}
\multicolumn{3}{l}{ Berdasarkan } \\
pelaksanaan pelatihan \\
selama 2 & hari, \\
kehadiran & peserta \\
guru $>85 \%$ &
\end{tabular} & $\begin{array}{l}100 \% \text { dari } 14 \text { guru yang } \\
\text { mengikuti pelatihan hadir } \\
\text { selama kegiatan } 2 \text { hari }\end{array}$ \\
\hline 2. & $\begin{array}{lr}\text { Respon } & \text { peserta } \\
\text { berkategori } & \text { sangat } \\
\text { baik } & \text { selama } \\
\text { mengikuti pelatihan }\end{array}$ & $\begin{array}{l}100 \% \text { guru memberikan } \\
\text { respon sangat antusias dalam } \\
\text { mengikuti pelatihan }\end{array}$ \\
\hline 3 & $\begin{array}{l}\text { Pemahaman dan } \\
\text { keterampilan guru } \\
\text { berkategori sangat } \\
\text { baik, seluruh peserta } \\
\text { mampu membuat soal } \\
\text { quis interaktif } \\
\text { menggunakan } \\
\text { Quizizz }\end{array}$ & $\begin{array}{l}85 \% \text { peserta pelatihan dapat } \\
\text { mengembangkan terhadap } \\
\text { berinovasi pembuatan Quiz interaktif, } 15 \\
\text { \% guru lain masih mengalami } \\
\text { kesulitan, karena belum } \\
\text { familiar terhadap penggunaan } \\
\text { teknologi }\end{array}$ \\
\hline
\end{tabular}

\section{Kesimpulan dan Saran}

Program pelatihan pengembangan media pembelajaran ini bertujuan memberikan peningkatan kompetensi dan kreativitas guru dalam membuat kuis interaktif atau evaluasi pembelajaran secara online dengan memanfaatkan aplikasi Quizizz di masa pandemi covid-19. Tentunya dalam hal ini guru juga harus mampu terus berkreasi dan beradaptasi sesuai kebutuhan belajar anak di masa ini. Perkembangan kasus Covid-19 yang belum mereda saat ini, tentunya para guru harus terus menjadi ujung tombak pendidikan dalam mencerdaskan anak bangsa, dengan terus berkarya dan berinovasi dalam mengajar, walaupun dalam keterbatasan. Peran teknologi di masa saat ini sangatlah diperlukan, tidak hanya di masa pandemi saja, melainkan juga dibutuhkan dalam pembelajaran secara tatap muka sehingga guru dituntut untuk terus mengembangkan diri dalam penggunaan teknologi dalam proses pembelajaran baik secara luring maupun daring.

\section{REFERENSI}

[1] Rizqon Halal Syah Aji, "Dampak Covid-19 pada Pendidikan di Indonesia: Sekolah, Keterampilan, dan Proses Pembelajaran," SALAM, Jurnal Sosial \& Budaya Syar-i. Vol. 7, No. 5 2020. [Online]. http://journal.uinjkt.ac.id/index.php/salam/article/view/153 14/0. [Akses Agustus. 2, 2021].

[2] Wardani, Duhita Savira, Muhammad Rizal Fauzi, Ruwaida Zafira, dan Dian Kurniawati, "Creating Props: Improving Writing Skills of Teaching Materials of Elementary Teacher Education Students through Project-Based Learning," Mimbar Sekolah Dasar, Vol. 7(2) 2020, 216-234. [Online]. 
https://ejournal.upi.edu/index.php/mimbar. [Akses Agustus.

$5,2021]$.

[3] Sekretariat Nasional Satuan Pendidikan Aman Bencana,

Kementerian Pendidikan dan Kebudayaan Republik

Indonesia; 2020. [Online]. Tersedia:

https://gtk.kemdikbud.go.id/read-news/bersama-hadapicorona-update-penanganan-covid19-bidang-pendidikan [Akses : Juni. 21, 2021].

[4] Irwan, I., Luthfi, Z. F., dan Waldi, A, "Efektifitas Penggunaan Kahoot! untuk Meningkatkan Hasil Belajar Siswa [Effectiveness of Using Kahoot! to Improve Student Learning Outcomes]," Pedagogia, Jurnal Pendidikan Vol 8, $\begin{array}{llll}\text { No } & 1 & 2019 . & \end{array}$ http://ojs.umsida.ac.id/index.php/pedagogia/article/view/18 66. [Akses Juni. 15. 2021].

[5] Salsabila, Unik Hanifah, Iefone Shiflana Habiba, Isti Lailatul Amanah, Nur Asih Istiqomah, dan Salsabila Difany, "Pemanfaatan Aplikasi Quizizz Sebagai Media Pembelajaran Ditengah Pandemi Pada Siswa SMA," Jurnal Ilmiah Ilmu Terapan Universitas Jambi Vol 4 No 2 Desember 2020. [Online]. Tersedia: https://onlinejournal.unja.ac.id/JIITUJ/article/download/11605/10463. [Akses Agustus. 15.2021].

[6] Purwanto, A., Pramono, R., Asbari, M., Santoso, P. B., Wijayanti, L. M., Choi, C. H., \& Putri, R. S, "Studi Eksploratif Dampak Pandemi COVID-19 Terhadap Proses Pembelajaran Online di Sekolah Dasar," EduPsyCouns: Journal of Education, Psychology and Counseling Vol 2 No 1 2020. [Online]. Retrieved from https://ummaspul.ejournal.id/Edupsycouns/article/view/397. [Akses Juni. 15, 2021].

[7] Batubara, Hamdan Husein, and Delila Sari Batubara, "Penggunaan Video Tutorial Untuk Mendukung Pembelajaran Daring Di Masa Pandemi Virus Corona," Muallimuna, Jurnal Madrasah Ibtidaiyah Vol 5 No 22020 74-84. [Online]. http://ojs.uniskabjm.ac.id/index.php/jurnalmuallimuna. [Diakses Agustus. $10,2021]$.

[8] Mulyatiningsih, Endang, "Metode Penelitian Terapan Bidang Pendidikan," Bandung, Alfabeta 2014. [Online]. http://senayan.iain-

palangkaraya.ac.id/index.php?p=show_detail\&id $=11121 \&$ keywords=. [Diakses Agustus. 22, 2021]. 